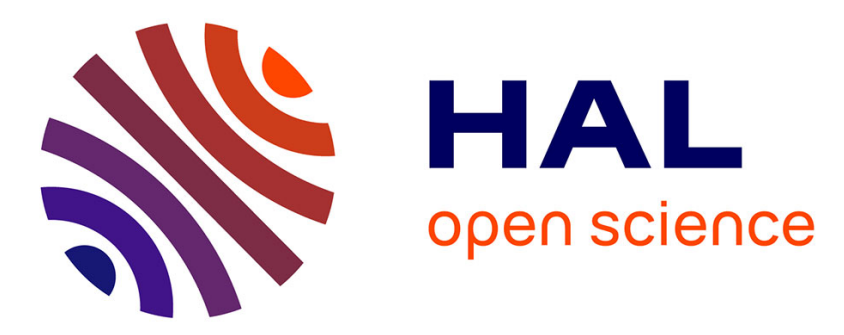

\title{
Developing a Collaborative Framework for Mapping and Managing Key Drivers of Future Value Creation Based on Intangible Assets
}

Stephane Pagano, Gilles Neubert

\section{- To cite this version:}

Stephane Pagano, Gilles Neubert. Developing a Collaborative Framework for Mapping and Managing Key Drivers of Future Value Creation Based on Intangible Assets. IFIP International Conference on Advances in Production Management Systems (APMS), Sep 2015, Tokyo, Japan. pp.62-69, 10.1007/978-3-319-22756-6_8. hal-01417399

\section{HAL Id: hal-01417399 \\ https://hal.science/hal-01417399}

Submitted on 16 Dec 2016

HAL is a multi-disciplinary open access archive for the deposit and dissemination of scientific research documents, whether they are published or not. The documents may come from teaching and research institutions in France or abroad, or from public or private research centers.
L'archive ouverte pluridisciplinaire HAL, est destinée au dépôt et à la diffusion de documents scientifiques de niveau recherche, publiés ou non, émanant des établissements d'enseignement et de recherche français ou étrangers, des laboratoires publics ou privés.

\section{(c)(1)}

Distributed under a Creative Commons Attribution| 4.0 International License 


\title{
Developing a collaborative framework for mapping and managing key drivers of future value creation based on Intangible Assets.
}

\author{
Stephane Pagano, Gilles Neubert \\ EMLYON Business School - UMR5600, \\ 23, avenue G. de Collongue, 69134 Ecully France \\ \{Pagano, GNeubert\} @EM-Lyon.com
}

\begin{abstract}
Companies, their suppliers and networks of partners need to be aligned to fulfill the strategy to deliver the value and adapt rapidly whatever challenge arises. To be resilient, companies and their networks have to build ecosystems in a systemic thinking. To help firms achieving this, we propose a methodology based on "value drivers" that allows the mapping, the analysis and the management of intangible assets, and the way they are activated through a multi perspective and a multi stakeholder framework.
\end{abstract}

Keywords: Value Creation, Collaborative Networks, Resilient SC, Ecosystem, Intangible assets, Stakeholders.

\section{$1 \quad$ Introduction}

In a rapidly changing environment, companies have to face many challenges while the competitive and technological environment keeps evolving at a fast pace: Globalization of markets through trade agreements and communication technologies, consumers' maturity and power of influence; strong trend towards a service-focused and dematerialized economy. Today's value chains consist of globally spread stakeholders, production processes, global distribution and retail channels. As part of the procurement process, the purchasing function is a hub upstream the Supply Chain that plays a fundamental role both in term of value creation and adaptation of the business models of the companies.

Our research objective is to construct a dictionary of resources at work in processes, seen here as drivers of performing relationships, by mapping their importance and role in the interactions taking place in the processes. Our applied research proposition is to build tools for the management of value creation in the buying and supply-chain processes integrating multiple stakeholders and multiple perspectives.

The paper is organized as follow: after the introduction, the second part reviews essential concepts underlying the stakes for the sustainability and the performance of firms' supply chain, the third part presents our framework approach and gives some 
details on our research and propositions. The fourth part concludes on findings, expected contributions and future operational outputs.

\section{Context}

\subsection{Value and value creation}

Value is a multi-perspective concept that extends beyond the limits of the firm. With globalization and technological innovation, value is delivered through dynamic networks or chains of interconnected firms or supply chain. This raises the question on how a particular relationship helps a firm creating value in terms of offerings, and what factor(s) are essential to successfully establish a particular relationship [1]. The strategic models of Value Creation based on arms-length confrontation with suppliers has led many companies on a short term value creation path, which meant value destruction for many suppliers and their economic ecosystem, impacting their entire value chain and their stakeholders.

\subsection{Corporate Social Responsibility}

There's an increasing pressure to consider the environmental and social aspects in purchasing policies: expectations are rising from stakeholders such as customers, the general public, NGOs, and governments who now hold companies responsible, not only for their own actions, but also all the partners within the supply chain $[2,3,4,5]$. CSR advocates the idea that companies need to change their business models and value propositions, actually creating value not only for themselves, but also for a larger number of stakeholders. Since 1930, the stakeholder theory poses the question of the definition of the objectives of firms, arguing about shareholders value or about sharing value with partners. Porter and Kramer recently introduced the idea of Shared Value [6]. Over the last decade, many authors [7, 8, 9] called for an urgent renewal of the strategic objectives of firms, towards financial success, but taking into account the actual needs of the communities where they operate or have an impact.

\subsection{Collaboration and risks mitigation}

Usual strategies based on competitive advantage [10,11] can't last. To address this issue, firms have investigated other domains: process optimization to save resources, flexibility, changes in relationship with other partners to secure exclusive access to suppliers. These developments impact the complexity and importance of purchasing decisions [12, 13, 14]. Supplier management is a key issue in supply chain performances and this reflects in a continuing growth of publications $[15,16,17,18]$. Since suppliers can represent up to $90 \%$ of firms turnover, the potential impact of inappropriate portfolio management of suppliers can seriously impact the value of a company. Firms also interconnected with their societal, natural and economic environment [19] because it's from these that depend their competitiveness: trained employees, infrastructures, communications, political stability. The state of the global 
environment therefore impacts the firms activity, operational costs, the availability of the resources, and the value of the firms viewed by the stakeholders. These risks are putting a high pressure on companies that need to adapt rapidly to innovative or disruptive situations.

\subsection{The role of intangible assets}

The way value is generated lies in the way physical and intellectual resources are managed and activated. Companies are looking for durable and sustainable strategic resource to acquire and maintain competitive advantages. This is why knowledge management should be completely integrated [20, 21, 22]. The importance of knowledge in the success of firms has already been described [23, 24] specifically the role of intangible assets in providing sustainable competitive advantage $[25,26]$. Though there is an abundant literature in economy and management on intangibles assets [27], we think that there is still a great work to do to operationalize intangible assets management, moreover in operations and supply chain management.

\subsection{Conclusion}

We see the complexity of supply chain and value chain configuring when it comes to describe how intangibles assets such as human competencies, organizational knowledge and behavioral characteristics deployed by interacting individuals, departments and organizations achieve each stakeholder's values, expectations and perspective. The "life" of projects and processes such as buyer-supplier relationship can be as complex as a human based interaction between organizations and services can be, because it greatly relies on organizational and personal "qualities" of the actors on both sides of each relation (buyers, vendors, and other stakeholders involved).

As value creation has many meanings, we see the limits of closed-off reasoning and the potential of widening the perspectives of firms through a paradigm shift: stakeholders, environment and future generations no longer being expandable when building sustainable business models and value creation strategies. This requires considering internal organization of the firm, its networks of connections and partners, its tangible and intangible assets and the notions of capital and investment [28].

\section{Approach and empirical method development}

Firms need to adopt a multi-perspective approach on the supplier selection and management: purchasing process and supply chain play a strategic role, which must go beyond optimization of processes, and take into account the temporal dimensions of the ROI (short, mid and long term) and the management of intangibles.

Measure, management and value creation in the firm are spread over time and must take into account the stakeholders. To ensure the longevity of the firm, the following dimensions and perspective must be included in the processes: 
- The time horizon of the firms' strategies;

- Value creation/destruction for the firm and its ecosystem;

- Actual place of intangible assets as drivers of competitiveness and value creation.

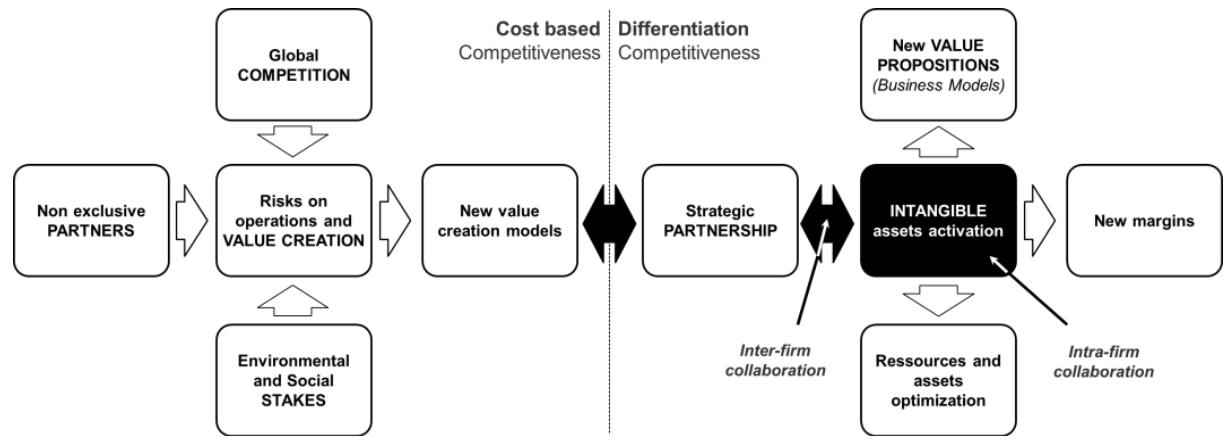

Fig. 1. Placing intangible assets at the heart of renewed value propositions.

To achieve this, we are constructing on an approach by value "enablers" or "drivers" for future value creation [29], mapping intangible assets, processes and stakeholders through events that will generate new value proposition (figure1) and eventually economic value and performance for the firm.

\subsection{Ground of the research}

The global research ground for our projects is based on three companies which offered participating buyers teams for initial explorations. Later on two firms offered a long standing participation for the conduct of the full research, currently ongoing, through long standing projects involving transversal teams.

\subsection{Connecting the intangibles}

To map and understand interactions and flows beyond the specifics of each situation (project, company, process, industry etc.), instead of trying to provide predefined items, we focused on building a generic methodology to analyze and manage value creation in the processes, objectively linking the activation of intangible assets to value creation. The applied output can be used by managers to follow projects and processes along their lifetime, and comprises four main phases: A consistency strategy analysis; the identification of key drivers; the selection of key performance indicators and the construction of dashboards.

The heart of the methodology is to analyze the drivers represented by intangible assets (human capital, relational capital, structural capital) and connect them with the process to achieve value proposition and delivery made to the clients. 

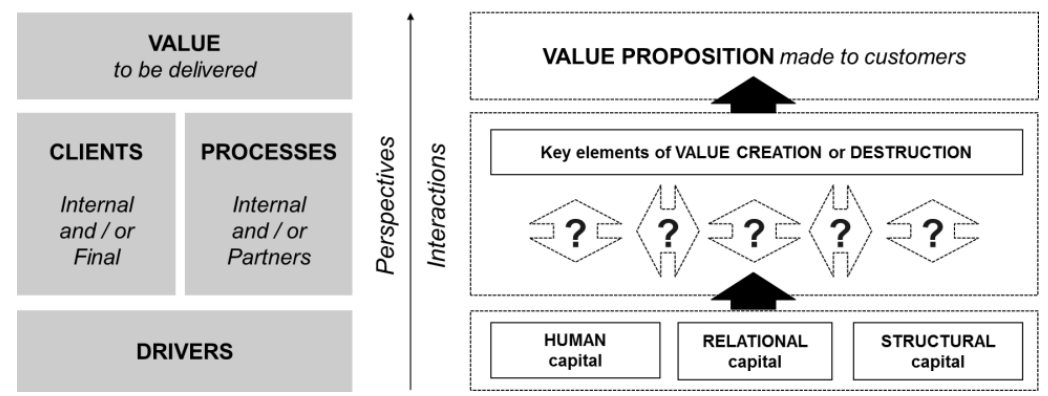

Fig. 2. The fuzzy box.

To do so, we need to clarify what happens in what we call a fuzzy box (figure 2) where players activate processes and stakeholders to achieve objectives and create value. Key steps here are to identify helping events occurring during the life of the project to evaluate the role and contribution of intangibles assets, and breaking events to capitalize on experience and construct feedback.

\subsection{Mapping value created / destroyed and stakeholders' impact.}

We have elaborated an interactive tool that allows the mapping, contextualization and linking of the stakeholders, their interactions and the value created or destroyed for each one of them (figure3). The different stakeholders of a project or process are listed twice: Underneath the time line, each stakeholder has its own timeline to position the source of helping and breaking events. Above the timeline, the same stakeholders are listed with once again their own timeline to position the different impacts of the events: value created or destroyed, assets created.

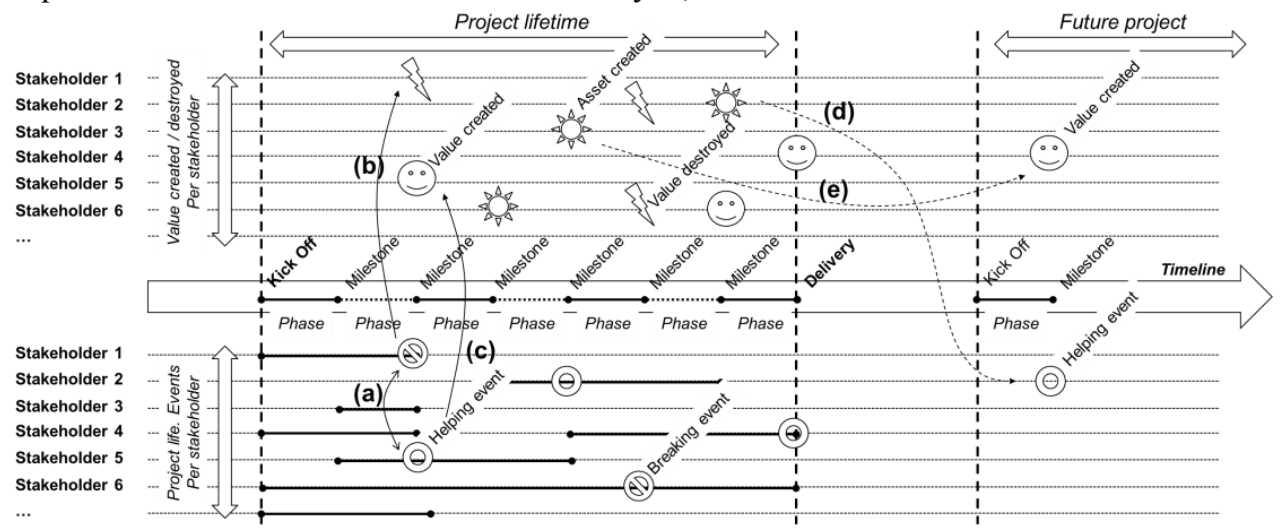

Fig. 3. Visual canvas, mapping events, value and stakeholders' interactions.

Helping and breaking points of the projects' life are positioned on the timelines. The interaction of the events (a) are visually mapped. When an event is positioned, it is possible to map the value destruction caused by the breaking event (b) and the 
value created for each helping event (c). Causes and consequences are spread over time and can generate positive or negative impact on different horizons: short, medium and long. Hence, assets created during one project can be identified as a significant source of a helping event in a future project (d), or directly create value (e).

This is a capital notion we want to document because assets mobilized in one project are probably the result of a previous investment, just like assets generated in the current project can be drivers of future value, a concept that is at the core of our research work. This can have a significant impact on the affectation of costs and value in industries, because every production line is analyzed through return on investment.

\subsection{Empirical validation of the method}

To validate the method and the tools we have organized a workshop with a team from each of the firms. The objectives of the workshop were to validate the methodology, and to verify the ease of appropriation of the method and the tools, knowing that the concepts and approaches used by the tools were quite far of the everyday operations and scope of the participants.

All the team members found easy to list the stakeholders, to map the helping and breaking events, to connect the values generated, even though these values were outside of direct economic results, and to point value destructions for the different stakeholders. A very significant result is that the method offered the possibility to identify and map the ripple effects of the outcomes of a given project, allowing the affectation of more value to the global outcome of a project due to previously unaccounted dissemination to other projects. Comments were here that the method offered unsuspected outputs: some assets generated are reusable and thus multiplying their effects and value while remaining unaccounted or miss-affected. Value generated by one team could be capitalized by third parties without recognition of the original creators. Some assets generated by one project could be integrated in an innovative Business Models not foreseen before.

The results showed that the buyers and the managers of the purchasing departments easily grab the approach and tools, both to build a reflexive dialogue on past experiences, where they try to identify solutions to achieve better performances, but also to elaborate a decisive argumentation to promote the strategic role of the purchasing function. All participants noted that the method could be used as a knowledge management tool to communicate the history of a project, to illustrate the history of the relationship with a supplier, allowing the understanding of the factors, namely human related, that were decisive along the projects phases.

\section{$4 \quad$ Conclusion and future works}

Our approach to integrate in the same framework different types of value (i.e. economic, monetary but also market, image, competencies, organizational skills etc.) was validated. The method and tools allow the objectivization of the different values created or destroyed, and of the future values that will eventually be generated with 
the intangible assets activated or created. Very formalized processes can alter the adaptive capacities of companies and networks, building the case for the ability to build transversal qualitative approach of relationships and information sharing, all these heavily relying on the intangible assets of companies.

The ability for firms to adapt, reconfigure and respond, greatly relies on the capacity of the different stakeholders involved to collaborate and mutually adjust to each-others, diffuse information and realign. All this relies almost exclusively on the very own capacities of the actors involved thus illustrating the central importance of intangible assets. This research builds meaningful methods to track, document and manage intangibles assets in response to internal or external pressure on value creation.

Expected outputs are tools to: analyze the strategy of the firm, how it is translated along the supply chain; identify and take into account all the stakeholders; map, contextualize and link the stakeholders, their interactions and the value created or destroyed for each one of them. These deliverables are being developed and refined through field work. They describe, operationalize and value intangible assets, not in the book value of the firms, but in the future value they can generate or destroy. Other outputs are being developed in field now such as knowledge management tools.

Among scientific contributions, we expect this research will contribute to Resource-Based View theory, to Knowledge Management, to Sustainable Supply Chain and to Supply Chain performance.

\section{Aknowledgements}

The authors would like to thank THESAME and the PEAK program: member companies of the program, the F2I, funding structure of the UIMM, the UDIMERA, the Research Division of the Regional Council of Rhône-Alpes, and the General Council of Haute-Savoie.

\section{References}

1. Srivastava, V., Singh, T., Value creation through relationship closeness. Journal of Strategic Marketing 18, 3-17 (2010).

2. Jiang, B., The effects of interorganizational governance on supplier's compliance with SCC: An empirical examination of compliant and non-compliant suppliers. Journal of Operations Management 27, 267-280 (2009).

3. Kovács, G., Corporate environmental responsibility in the supply chain. Journal of Cleaner Production 16, 1571-1578 (2008).

4. Goebel, P., Reuter, C., Pibernik, R., Sichtmann, C., The influence of ethical culture on supplier selection in the context of sustainable sourcing. IJPE, Sustainable Development of Manufacturing and Services 140, 7-17 (2012).

5. Igarashi, M., de Boer, L., Fet, A.M., What is required for greener supplier selection? A literature review and conceptual model development. Journal of Purchasing and Supply Management 19, 247-263 (2013).

6. Porter, M.E., Kramer, M.R., Creating Shared Value. HBR 89, 62-77 (2011). 
7. Hughes, J., Weiss, J., Simple Rules for Making Alliances Work. Harvard Business Review 85, 122-131 (2007).

8. Murphy, P., Shareholders First? Not So Fast.. HBR 87, 126-127 (2009).

9. Ready, D.A., Truelove, E., The Power of Collective Ambition. Harvard Business Review 89, 94-102 (2011).

10. Porter, M.E., Competitive advantage: creating and sustaining superior performance: with a new introduction, 1st Free Press ed. ed. Free Press, New York (1998).

11. Barney, J., Firm Resources and Sustained Competitive Advantage. Journal of Management 17, 99 (1991).

12. De Boer, L., Labro, E., Morlacchi, P., 2001. A review of methods supporting supplier selection. European Journal of Purchasing \& Supply Management 7, 75-89 (1991).

13. Weele, A.J. van, Purchasing \& supply chain management: analysis, strategy, planning and practice. Cengage Learning, Andover (2010).

14. Oshri, I., Kotlarsky, J., Willcocks, P.L.P., The Handbook of Global Outsourcing and Offshoring. Palgrave Macmillan (2011).

15. Ho, W., Xu, X., Dey, P.K., Multi-criteria decision making approaches for supplier evaluation and selection: A literature review. European Journal of Operational Research 202, 16-24 (2010).

16. Cao, M., Zhang, Q., Supply chain collaboration: Impact on collaborative advantage and firm performance. Journal of Operations Management 29, 163-180. (2011).

17. Wu, C., Barnes, D., A literature review of decision-making models and approaches for partner selection in agile supply chains. Journal of Purchasing and Supply Management 17, 256-274 (2011).

18. Chai, J., Liu, J.N.K., Ngai, E.W.T., Application of decision-making techniques in supplier selection: A systematic review of literature. Expert Systems with Applications 40, 38723885 (2013).

19. Porter, M.E., Kramer, M.R., The Competitive Advantage of Corporate Philanthropy. Harvard Business Review 80, 56-69 (2002).

20. Drucker, Coming of the New Organization. Harvard Business School Reprint (1988).

21. Barney, J., Firm Resources and Sustained Competitive Advantage. Journal of Management 17, 99 (1991).

22. Grant, R.M., The Knowledge-based View of the Firm: Implications for Management Practice. Long Range Planning 30, 450-454 (1997).

23. Drucker, P.F., Long-Range Planning-Challenge to Management Science. Management Science 5, 238-249 (1959).

24. Penrose, E.T., The theory of the growth of the firm. Oxford University Press, Oxford; New York (1995).

25. Hall, R., A framework linking intangible resources and capabiliites to sustainable competitive advantage. Strat. Mgmt. J. 14, 607-618 (1993).

26. Hall, R., The strategic analysis of intangible resources. Strategic. Management Journal. 13, 135-144 (1992).

27. Sveiby, K.-E., Methods for Measuring Intangible Assets [WWW Document]. URL http://www.sveiby.com/articles/IntangibleMethods.htm (accessed 5.16.14).

28. Parung, J., Bititci, U.S., A metric for collaborative networks. Business Process Management Journal 14, 654-674 (2008).

29. Marr, B., Schiuma, G., Neely, A., Intellectual capital - defining key performance indicators for organizational knowledge assets. Business Process Management Journal 10, 551-569 (2004). 